\title{
SISTEM PERJODOHAN ANAK DI KECAMATAN MANGGALA KOTA MAKASSAR
}

\author{
Oleh: Nur Fadhila Andini ${ }^{*}$, Andi Agustang ${ }^{2}$ \\ ${ }^{12}$ Program Studi pendidikan Sosiologi Fakultas Ilmu Sosial dan Hukum \\ Universitas Negeri Makassar \\ Email: nurfadhilaandini8@gmail.com ${ }^{1}$, andiagustang@unm.ac.id ${ }^{2}$
}

\begin{abstract}
Abstrak
Penelitian ini bertujuan untuk mengetahui 1) Strategi orang tua dalam menentukan jodoh anak agar keinginannya dapat dipenuhi. 2) Faktorfaktor yang melatarbelakangi orang tua dalam perjodohan anak. Jenis penelitian ini merupakan penelitian kualitatif. Jumlah informan dalam penelitian ini sebanyak 6 orang yang di tentukan melalui teknik purposive sampling dengan kriteria informan yaitu diantaranya anak dan orang tua di Rt 06 Kecamatan Manggala, sudah menikah berusia (17-65 tahun). Teknik penggumpulan data yaitu observasi, wawancara, dan dokumentasi. Pemeriksaan keabsahan data dilakukan dengan member checking. Hasil penelitian menunjukkan bahwa 1) Strategi orang tua dalam menentukan jodoh anak agar keinginannya dapat dipenuhi. Yaitu terdapat dua strategi a) membujuk adalah berusaha meyakinkan seseorang bahwa yang dikatakannya benar, b) meyakinkan adalah seseorang yang percaya atas apa yang mereka katakan 2) Faktor-faktor yang melatarbelakangi orang tua dalam perjodohan anak. Yaitu terdapat tiga faktor a) faktor ekonomi, perjodohan ini terjadi karena keadaan keluarga yang hidup di garis kemiskinan bawah, b) faktor pendidikan, perjodohan ini terjadi karena ingin menikahkan anaknya dengan seseorang yang sama dengan pendidikan anaknya, c) faktor keluarga, perjodohan ini terjadi agar hubungan mereka tetap dekat.
\end{abstract}

Kata Kunci: Sistem perjodohan, Anak, Kecamatan Manggala

\section{PENDAHULUAN}

Perjodohan adalah hubungan yang permanen antara laki-laki dan perempuan

yang diikuti oleh masyarakat yang bersangkutan berdasarkan atas peraturan perjodohan yang berlaku dalam suatu perkawinan untuk mewujudkan adanya keluarga dan memberikan adanya keabsahan atas status kelahiran anak-anak mereka (Rahman, M.M., 2015). Perjodohan tidak hanya mewujudkan adanya hubungan antara mereka yang jodoh saja tetapi juga melibatkan hubungan-hubungan diantara kerabat-kerabat dari masing-masing pasangan tersebut. Perjodohan adalah suatu pernikahan yang diatur oleh orang tua atau kerabat dekat untuk pasangan, dan biasanya dilakukan pada perempuan remaja akhir yang nantinya akan memerlukan banyak penyesuaian setelah menikah. (Fadhli, 2020)(Awaru, 2021) 
Perjodohan yang ada di RT o6 Kecamatan Manggala pada umumnya dilakukan oleh pihak keluarga yang ingin anaknya menikah dengan kerabatnya. Artinya keluarga memilih calon menantu yang baik bagi anak mereka. Di tengah-tengah masyarakat, sikap "berhati-hati" dalam mempertimbangkan berbagai faktor yang terkait dengan pelaksanan perjodohan adalah hal yang wajar, karena perjodohan diharapkan akan berlanjut ke pernikahan dengan baik dan langgeng seumur hidup. Pemilihan calon menantu lazimnya tidak berdasarkan kedudukan, akan tetapi budi pekerti serta pekerjaan seseorang sangat menentukan perjodohan dapat terlaksana. Kerabat yang miskin boleh saja ingin memiliki perempuan calon istri dari kerabat yang kaya tetapi pihak lelaki harus mampu menawarkan sesuatu yang cukup menarik, agar menjadi penilaian bagi pihak perempuan demikian pula sebaliknya

Hal ini dilakukan oleh orang tua sebagai salah satu jalan untuk dapat menikahkan anaknya dengan seorang yang menurut mereka dianggap cocok atau pantas. Namun, pada dasarnya pilihan yang terbaik menurut orang tua belum tentu tepat untuk anaknya sehingga wajar jika perceraian kerap terjadi. Selain itu ini sangat sering terjadi di lingkungan sekitar kita (Agustang, 1999). Perjodohan yang semacam ini bukan hanya menimbulkan keretakan rumah tangga, bahkan memicu terjadinya perceraian yang tentunya akan menimbulkan dampak tekanan batin serta buruk bagi psikologis, kesehatan serta depresi yang dapat menyerang tiap pasangan. (Akbar 2021)

\section{METODE PENELITIAN}

Pendekatan penelitian yang digunakan dalam penelitian ini adalah pendekatan deskriptif dengan jenis penelitian kualitatif. Dalam penelitian ini mengambil lokasi di Rt o6 Kecamatan Manggala Kota Makassar. Penelitian ini berfokus pada anak dan orang tua di Rt 06 Kecamatan Manggala. Pendekatan deskriptif adalah data yang dikumpulkan berupa kata-kata, gambar, dan bukan angka-angka. Semua yang dikumpulkan berkemungkinan menjadi kunci terhadap apa yang sudah diteliti (Sugiyono, 2013) Adapun tahap-tahap penelitian yang dilakukan dalam penelitian ini secara garis besar yaitu tahap pra penelitian, tahap penelitian, dan tahap akhir. Sumber data yang digunakan yaitu sumber data primer dan sumber data sekunder. Jumlah informan sebanyak 6 orang yang dipilih menggunakan teknik purposive sampling. Teknik pengumpulan data dengan metode observasi, wawancara dan dokumentasi. Pemeriksaan keabsahan data menggunakan teknik member checking. Teknik analisis data meliputi reduksi data, penyajian data, dan penarikan kesimpulan.

\section{PEMBAHASAN}

\section{Strategi Orang Tua Dalam Menentukan Jodoh Anak Agar Keinginannya Dapat Dipenuhi}

Strategi orang tua dalam menentukan jodoh anak agar keinginannya dapat dipehuhi, disini anak harus mengikuti keinginan orang tuanya walaupun dalam keadaan 
terpaksa. Orang tua harus memberikan pengertian dalam hal perjodohan agar anak mampu menerima langsung. Orang tua dapat membujuk anaknya agar menerima perjodohan tetapi ada beberapa anak yang awalnya menolak setelah dibujuk berapa kali barulah mengiyakan perjodohan. Adapun anak yang harus diyakinkan terlebih dahulu sebelum menerima perjodohan, sebagai orang tua harus memberikan pengertian kepada anak tentang perjodohan dari sisi negatif dan positifnya agar anak yakin bahwa perjodohan itu ada baiknya serta pilihan orang tua yang terbaik. (Darmadi, 2012)

Rustan \& Hakki (2017) Membujuk adalah berusaha meyakinkan seseorang bahwa yang di katakannya benar. Membujuk anak dalam artian meyakinkan bahwa yang dilakukan oleh orang tua mengenai perjodohan adalah sangat baik karena orang tua ingin melihat anaknya bahagia walaupun dengan pilihannya. Orang tua juga memilihkan pendamping untuk anaknya yang ia kenal sebelumnya, sehingga anak tersebut mau menerimanya walaupun awalnya anaknya menolak untuk di jodohkan tapi sebagai orang tua mampu membujuk anaknya bahwa perjodohan tersebut ada baiknya

Pilihan orang tua terkadang memang ada baiknya tapi balik lagi kepada si anak bagaimana dia menjalaninya dengan baik. beberapa anak awalnya menolak perjodohan tersebut, tapi dengan begitu orang tua bisa membujuk anaknya dengan caranya sendiri. Ada beberapa anak yang tidak menyukai perjodohan tetapi si anak tidak tega melihat orang tuanya yang selalu membujuk sampai terkesan memohon. Kemudian si anak menerimanya dengan sepenuh hati mengenai perjodohan karena tidak ingin melihat orang tuanya kecewa.

Kata yang sering orang tua katakan untuk anaknya dalam membujuk adalah "terima mi ini perjodohan nak, ini permintaan orang tua". Laki-laki pilihan orang tua ini baik dan orang tua juga tidak akan salah memilih, Insya Allah kehidupan kedepannya bakalan terjamin.Disisi lain ada orang tua yang mrngatakan "kalau kita terima ini perjodohan, semua yang kita inginkan bakalan ku penuhi asalkan di terima ini perjodohan karena kalau tidak kita terima orang tua malu dengan keluarga yang lain apa lagi keluarga laki-laki”. Kemudian si anak berfikir dengan baik tentang perjodohan ini karena dia tidak mau mengecewakan orang tuanya dan keluarga yang lain.

Ada salah satu anak yang mengatakan bahwa "disini orang tua membujuk saya agar menerima perjodohan ini, salah satu alasannya dengan masalah ekonomi, keluarga pria memang terlihat berada di bandingkan dengan keluarga saya maka dari itu saya menerima perjodohan ini karena masalah ekonomi”. Anak yang di jodohkan terpaksa menerimanya karena masalah ekonomi, dengan begitu dia bisa memenuhi keinginan orang tuanya. Terkadang banyak anak yang tidak ingin di bujuk dalam masalah perjodohan, akan tetapi anak yang melihat usaha orang tuanya dalam mencarikan pasangan hidup adalah hal yang baik menurut mereka.

Sebelum anak mereka di jodohkan, orang tua pasti menanyakan mengenai hal ini. Maka dari itu banyak yang tidak menginginkan dan ada juga yang langsung mengiyakan. Anak yang tidak mengiyakan perjodohan ini sudah pasti orang tua 
membujuknya dengan sepenuh hati mengenai perjodohan agar mereka mampu menerimanya.

Zubaidillah dan Hasan, H (2019) Anak yang di jodohkan sudah pasti belum memiliki rasa cinta dan sayang terhadap laki- laki tersebut. Tapi dengan begitu dia terhindar dari fitnah. Orang tua juga ada baiknya menjodohkan anaknya agar terhindar dari hal yang tidak di inginkan. Banyak yang menginginkan anaknya bahagia dengan pasangannya walaupun akhirnya memilih pasangan dengan cara di jodohkan, lama kelamaan akan tumbuh rasa cinta dan sayang. Tidak ada yang tidak mungkin, semua orang berhak bahagia dan prosesnya bedabeda. Ada yang langsung menikah dengan pasangannya dan ada juga yang menikah karena di jodohkan.

Lain halnya dengan meyakinkan anak dalam perjodohan. Meyakinkan adalah seseorang yang percaya atas apa yang mereka katakan. Meyakinkan dapat mempercayai seseorang agar apa yang di katakannya selalu benar. Meyakinkan seorang anak dalam hal perjodohan sudah pasti apa yang orang tua katakan selalu benar. Tetapi terkadang ada anak yang menolak perjodohan, jadi sudah pasti harus di yakinkan terlebih dahulu agar mereka percaya bahwa yang orang tua katakan ada baiknya.

Orang tua yang meyakinkan anaknya untuk menikah dan tidak salah memilih pasangan itu adalah orang tua yang ingin melihat anaknya bahagia walaupun dalam keadaan terpaksa (Hartono, 2017). Tetapi dengan begitu si anakmampu memenuhi permintaan orang tuanya. Banyak anak yang awalnya menolak ingin di jodohkan akan tetapi setelah di yakinkan mengenai perjodohan barulah anak itu sadar bahwa yang orang tua katakan ada baiknya. Disini orang tua harus lebih meyakinkan anaknya bahwa apa yang dia katakan tentang perjodohan itu baik, sehingga anak yang di jodohkan sudah tau mengenai perjodohan.

Untuk meyakinkan anak dalam sebuah perjodohan, tergantung dari orang tua bagaimana meyakinkan anaknya untuk menerima perjodohan. Ada anak yang baru di yakinkan bahwa perjodohan itu adalah baik dia langsung menerimanya, tetapi ada juga anak yang di yakinkan bahwa perjodohan itu adalah baik dia menolaknya terlebih dahulu. Setelah di yakinkan terus barulah dia sadar apa yang di katakan orang tuanya baik menurut mereka.(Januar 2020)

Dalam hal ini semua anak menerima perjodohan dalam keadaan terpaksa dan ada juga dalam keadaan maunya sendiri karena tidak ingin mengecewakan orang tuanya sehingga orang tua sudah membujuk dan meyakinkan agar menerima perjodohan tersebut.

Perjodohan yang di terima dalam keadaan terpaksa kadang merugikan kedua pihak tetapi balik lagi kepada si anak bagaimana dia menjalaninya. Bukan berarti hubungan perjodohan tidak bakalan bahagia, terkadang pacaran setelah menikah pun lebih bahagia dari pada hubungan yang lama tapi tidak ada kepastian (Wagianto, 2017). Banyak perempuan seperti ini, mereka masih pacaran lama-lama tapi mereka tidak di 
beri kepastian kepada laki-laki sehingga jalan satu-satunya adalah menerima orang baru yang sudah pasti ada kepastiannya.

Maka dari itu orang tua harus memilihkan dengan baik pendamping bagi anaknya. Yang awalnya anak menolak perjodohan, tapi kelamaan dia menerimanya karena melihat orang tua lebih banyak tanggung jawab dalam memilihkan pasangan. Anak juga tidak tega melihat orang tuanya yang sering kali memohon hanya karena keinginan orang tuanya harus di penuhi.

Jadi disini orang tua harus memilihkan pasangan yang baik untuk anak-anaknya agar kedepannya tidak salah memilih dan pernikahan anaknya tidak jadi korban hanya karena melihat orang tua ingin menikahkan anaknya yang ingin dijodohkan yang belum siap. Jangan memaksakan pilihan anak, jika sudah menginginkan untuk menikah maka segeralah carikan pasangan yang baik menurut orang tua.

Teori Homogami berhubungan dengan hasil penelitian yang dilakukan oleh peneliti karena dari teori homogami ini seseorang cenderung akan lebih memilih individu yang memiliki banyak kesamaan dengan dirinya sendiri seperti memiliki pemikiran, pendapat, sikap, nilai dan kepercayaan yang dianggap sama. Kebanyakan pernikahan yang bersifat hhomogen menentukan pilihan berdasarkan atas kelompok umur, tinkat pendidikan, selera umor, bentuk fisik serta status sosial ekonomi.(Kusumaningtyas \& Hakim, 2019)

Dalam teori pemilihan jodoh, teori homogami digunakan untuk menganalisis sejauh mana orang tua dari kalangan keluarga yang ikut terlibat dalam proses pemilihan jodoh yang dilakukan oleh anak hingga akhirnya sang anak memutuskan untuk melakukan pernikahan. Pemicu utama terjadinya perjodohan adalah strategi orang tua yang diikuti oleh faktor pendukung (Hidayatulloh,dkk 2018). Sistem perjodohan dalam penelitian ini lebih mengarah pada sistem perjodohan dengan jenis endogami yaitu orang tua atau keluarga mengharuskan anaknya memilih jodoh di lingkungan kelompoknya sendiri.

\section{Faktor-faktor Yang Melatarbelakangi Orang Tua Dalam Perjodohan Anak}

Qibtiyah (2015) setiap perjodohan yang dilakukan biasanya disebabkan beragam latar belakang sosial, adapun dalam hasil penelitian ini terdapat Faktor yang melatarbelakangi orang tua dalam menjodohkan anaknya . hal ini dapat dilihat dari beberapa faktor diantaranya, faktor ekonomi berdasarkan yang diungkapkan informan kepada peneliti bahwa faktor ekonomi menjadi paling utama seseorang dijodohkan karena ingin membahagiakan kedua orang tua serta mengangkat derajat keluarga. Meskipun demikan ada yang menolak dijodohkan tetapi setelah diberi pengertian tentang pernikahan barulah dia menerimanya.

Disini faktor pendidikan juga menjadi salah satu faktor yang melatarbelakangi orang tua dalam perjodohan anak, berdasarkan yang di ungkapkan oleh informan kepada peneliti bahwa faktor pendidikan sangat penting untuk kehidupan tapi tidak 
semua orang tua bisa melanjutkan pendidikan anak-anaknya. Sebagaian orang tua menginginkan mempunyai anak dan menantu yang sama pendidikannya, hanya saja ada yang benar-benar dijodohkan yang sama pendidikannya dan ada juga yang tidak tergantung orang tua anak tersebut mencarikan jodoh yang memang menurut dia baik.

Terakhir faktor keluarga yang melatarbelakangi orang tua dalam perjodohan anak, berdasarkan yang di ungkapkan oleh informan kepada peneliti bahwa faktor keluarga juga termasuk, karena orang tua menginginkan perjodohan terjadi dengan keluarga sendiri agar hubungan kekeluargaan menjadi tetap kuat meskipun sudah dekat.

\section{PENUTUP}

Perjodohan adalah hubungan yang permanen antara laki-laki dan perempuan yang diikuti oleh masyarakat yang bersangkutan berdasarkan atas peraturan perjodohan yang berlaku dalam suatu perkawinan untuk mewujudkan adanya keluarga dan memberikan adanya keabsahan atas status kelahiran anak-anak mereka. Adapun strategi orang tua dalam menentukan jodoh anak agar keinginannya dapat dipenuhi: a) Membujuk adalah berusaha meyakinkan seseorang bahwa yang dikatakannya benar. b) Meyakinkan adalah seseorang yang percaya atas apa yang mereka katakan. 2) Faktorfaktor yang melatarbelakangi orang tua dalam perjodohan anak, a) Faktor ekonomi, perjodohan ini terjadi karena keadaan keluarga yang hidup di garis kemiskinan. b) Faktor pendidikan, perjodohan ini terjadi karena ingin menikahkan anaknya dengan seseorang yang sama dengan pendidikan anaknya juga. c) Faktor keluarga, perjodohan ini terjadi agar hubungan mereka tetap dekat meskipun umurnya belum matang untuk melangsungkan pernikahan.

\section{DAFTAR PUSTAKA}

Agustang, A. (2021, January 10). INTERAKSI SOSIAL KOMUNITAS LOKAL DENGAN PENDATANG DAN PERUBAHAN STRUKTUR KOMUNITAS LOKAL (Studi pada Masyarakat Majemuk di Kawasan Industri Makassar). https://doi.org/10.31219/osf.io/pw5xr

Agustang, A. (2021, January 22). Filosofi Research Dalam Upaya Pengembangan Ilmu. https://doi.org/10.31219/osf.io/9n6za

Oruh, S., Agustang, A., \& Asrifan, A. (2021, January 9). PENGARUH PENGETAHUAN KELUARGA, STIGMA MASYARAKAT DAN KEPATUHAN MINUM OBAT TERHADAP KEKAMBUHAN PENYAKIT GANGGUAN JIWA DI KOTA MAKASSAR. https://doi.org/10.31219/osf.io/wxsg8

Agustang, A., \& Oruh, S. (2021, January 22). Teknologi Partisipasi Metode Fasilitasi Pembuatan Keputusan Partisipatif. https://doi.org/10.31219/osf.io/dhfb7

Oruh, S., Agustang, A., \& Theresia, M. (2021, January 9). KESEJAHTERAAN 
Pinisi Journal Of Sociology Education Review; Vol. 1; No. 2; Juli 2021

Halaman 192-198

PSIKOLOGIS (Studi Pada Dewasa Madya yang Belum Menikah di Kota Makassar). https://doi.org/10.31219/osf.io/v5af8

Akbar, H., \& Dkk. (2021). Teori Kesehatan Reproduksi. Yayasan Penerbit Muhammad Zaini.

Awaru, A. O. T. (2021). Sosiologi Keluarga (Bahri (ed.)). Media Sains Indonesia. https://books.google.co.id/books?id=R9VDEAAAQBAJ

Darmadi, E. (2012). KONSEP DIRI PADA JANDA CERAI. Skrpsi S1. UNIVERSITAS ISLAM NEGERI SUNAN KALIJAGAYOGYAKARTA.

Fadhli, Y. R. (2020). Remaja perempuan yang menikah melalui perjodohan: Studi fenomenologis tentang penyesuaian diri. Jurnal Ilmiah Psikologi Terapan, 8(2), Pp.153-159.

Hartono, J. (2017). PERNIKAHAN DI USIA MUDA KARENA PERMINTAAN ORANG TUA DI KECAMATAN MUARA BANGKAHULU. Qiyas: Jurnal Hukum Islam Dan Peradilan, 2(2).

Hasibuan, A.S. (2018). Otoritas Orang Tua Dalam Memaksa Kawin Anak Usia 21 Tahun Ditinjau Dari Kompilasi Hukum Islam (Studi Kasus Desa Sibual-buali. Kec. Ulu Barumun, Kab. Palas). (Doctoral Dissertation, Universitas Islam Negeri Sumatea Utara Medan).

Hidayatulloh, I., Putri, R., Ter Naotrue, R., \& Fedryansyah, M. (2018). Persepsi perkawinan usia dini dan pemberdayaan gender. Jurnal Pemikiran Dan Penelitian Sosiologi, 3(1).

Agustang, A., Oruh, S., \& Mahmuddin, H. (2022, January 4). IMPROVING THE QUALITY OF PRIMARY HEALTH SERVICES IN THE PERSPECTIVE OF PARTICIPATORY GOVERNANCE. https://doi.org/10.17605/OSF.IO/9T8VQ

Oruh, S. (2022, January 4). STRATEGI PENGEMBANGAN SUMBER DAYA MASYARAKAT KEPULAUAN YANG UNGGUL MENUJU SOCIETY 5.0. https://doi.org/10.17605/OSF.IO/SP42D

Oruh, S. (2022, January 4). Supplemental materials for preprint: KAU MAU KEMANA (Refleksi Sosiologis terhadap Integritas Upaya Kesehatan Jiwa). https://doi.org/10.17605/OSF.IO/CP39Z

Oruh, S., \& Agustang, A. (2022, January 4). KESEJAHTERAAN PSIKOLOGIS (Studi Pada Dewasa Madya yang Belum Menikah di Kota Makassar). https://doi.org/10.17605/OSF.IO/ZUSKV

Oruh, S., \& Agustang, A. (2022, January 4). PENGARUH PENGETAHUAN KELUARGA, STIGMA MASYARAKAT DAN KEPATUHAN MINUM OBAT TERHADAP KEKAMBUHAN PENYAKIT GANGGUAN JIWA DI KOTA MAKASSAR. https://doi.org/10.17605/OSF.IO/K4VMP

Agustang, A., \& Oruh, S. (2022, January 4). HEGEMONIC SOCIAL RELATION A Study of Sociology on Outsourcing Practice. https://doi.org/10.17605/OSF.IO/PJM3A

Oruh, S., Agustang, A., \& Agustang, A. D. M. P. (2021, December 21). SOCIAL DETERMINANTS OF COMMUNITY HEALTH WITH THE EVENT OF DIABETES MELLITUS (Study of Health Sociology in Makassar City). https://doi.org/10.31219/osf.io/4qvxf 